\title{
OS PRIMÓRDIOS DOS DIREITOS HUMANOS DA IDADE ANTIGA ATÉ A IDADE MÉDIA NA HISTÓRIA DA CIVILIZAÇÃO OCIDENTAL
}

\author{
Gisele Laus da Silva Pereira Lima ${ }^{1}$
}

\section{Resumo:}

O presente artigo busca a partir da matriz teórica do historicismo jurídico e sua dinâmica metodológica, valer-se de duas premissas: a história da civilização ocidental da Idade Antiga até a Idade Média e as transformações e o tratamento jurídico decorrentes do período, para apresentar o resgate histórico do desenvolvimento dos direitos humanos, frutos de uma constante construção contra a própria tirania do homem sobre o homem e do Estado, pois os primórdios sobre noções de dignidade, as proteções, conquistas, direitos e até restrições se explicam pela história.

Palavras-chave: Direitos Humanos; Contexto Histórico; Civilização Ocidental; Idade Antiga; Idade Média.

\section{THE PREMIODS OF HUMAN RIGHTS FROM THE OLD AGE TO THE AVERAGE AGE IN THE HISTORY OF WESTERN CIVILIZATION}

\begin{abstract}
:
From the theoretical matrix of legal historicism and its methodological dynamics, the present article seeks to draw on two premises: the history of Western civilization from the Old Age to the Middle Ages and the transformations and legal treatment of the period to present the Historical recovery of the development of human rights, the fruits of a constant construction against the very tyranny of man over man and the state, because the beginnings of notions of dignity, protections, conquests, rights and even restrictions are explained by history.
\end{abstract}

Keywords: Human Rights; Historical contexto; Western Civilization; Old age; Middle Ages.

\section{INTRODUÇÃO}

Para o desenvolvimento de uma pesquisa, em especial a jurídica, deve-se inicialmente escolher e adotar um referencial ou marco teórico, considerando o tratamento do problema que a pesquisa se propõe. Um enfoque teórico e de longo alcance são indispensáveis às atividades de pesquisa científica e à adequada compreensão dos problemas mais complexos com que, normalmente, se defronta o pesquisador. Os referenciais teóricos são correntes de

\footnotetext{
${ }^{1}$ Mestre em Direitos Difusos e Coletivos pela Universidade Metodista de Piracicaba/SP (UNIMEP). Professora das disciplinas de História do Direito, Direitos Humanos e Antropologia Jurídica na Universidade São Francisco Campus Itatiba e Bragança Paulista/SP
} 
pensamento, teorias de um ou vários autores já consolidadas pela comunidade científica, também chamada de teorias de base, matrizes teóricas ou grandes metodologias.

No início de um trabalho científico, geralmente, só se dispõe de alguns referenciais intuitivos. Deste modo, para o alcance do objetivo da pesquisa científica, deve-se partir de um conjunto de concepções teóricas, conceitos e categorias que estejam aptas a identificá-lo e descrevê-lo e, além disso, que sejam capazes de fornecer respostas diferentes daquelas já encontradas.

Seguindo essa dinâmica, a matriz teórica adotada para a elaboração da presente artigo foi a do historicismo jurídico. Subsequentemente, a linha de raciocínio adotada no processo de pesquisa, que forneceu as bases lógicas à investigação foi o dedutivo, com o objetivo de explicar o conteúdo das premissas e na relação com a conclusão.

O historicismo jurídico surgiu como corrente do pensamento jurídico entre os séculos XVII e XIX. Seu objetivo era propor a compreensão do fenômeno jurídico no ambiente social em que ele é produzido. Ao conceber o Direito como um corpo vivo, produto da realidade histórica e social, que se fundamenta na tradição e nos costumes de cada povo em determinado momento histórico, tal corrente de pensamento buscava na historicidade a resposta para quem contestasse a cientificidade do Direito. Para o historicismo jurídico o Direito era uma concepção histórica a partir do momento que é produto das relações sociais, das tradições e dos costumes de determinada sociedade nos seus específicos momentos históricos.

Tais preceitos formaram os elementos constituintes da doutrina elaborada na Escola Histórica do Direito ${ }^{2}$ pelo jurista Friedrich Car Von Savigny (1779-1861), que introduziu a teoria de Volksgeist, do "espírito do povo" na obra Da Vocação de Nosso Tempo para a Legislação e Jurisprudência, seguido de importantes autores como Gustav Hugo (1764-1844) e Georg Puchta (1789-1846).

A Escola Histórica do Direito procurou superar o obstáculo científico representado pela mutabilidade do Direito conferindo-lhe caráter predominantemente histórico. Foi nessa conjuntura, segundo Bobbio (1992, p.2), que o Direito passar a ser compreendido como

\footnotetext{
2 A expressão Escola histórica do Direito é empregada para designar uma corrente jurídico-filosófica desenvolvida originariamente na Alemanha durante o início do século XIX, que partia do pressuposto de que as normas jurídicas seriam o resultado de uma evolução histórica e que a essência delas seria encontrada nos costumes e nas crenças dos grupos sociais.
} 
conquista histórica, fruto de uma construção porque "é na evolução das sociedades e das culturas que o Direito adquire sua forma e definição."

Assim, partir de duas premissas: a história da civilização ocidental da Idade Antiga até a Idade Média e as transformações e o tratamento jurídico decorrentes do período, retirar uma terceira, logicamente decorrente das duas primeiras, denominada de conclusão, qual seja, o resgate histórico da construção dos direitos humanos no referido período.

A utilização interativa do referencial teórico do historicismo jurídico, do método dedutivo e do método auxiliar instrumental histórico inicia a estrutura formal do presente artigo e desencadeia o processo de pesquisa, permitindo a compreensão dos seus requisitos essenciais, para dar continuidade ao seu desenvolvimento.

E neste contexto que se busca no presente artigo elencar dentro do contexto histórico as situações gerais e particulares que possibilitaram a proteção do homem contra o arbítrio não só do Estado, mas também da sua própria tirania, pois eles foram fruto de um encadeamento.

Não há como negar que a conceituação e interligação com a ofensa a dignidade humana se firmou na modernidade ocidental, cenário em que os direitos humanos estavam vinculados, inicialmente a certas características da sociedade europeia dos séculos XVII e XVIII, com o surgimento do capitalismo e o impulso da economia de mercado e seus desdobramentos nas mais diversas áreas da ação sócio-política e jurídica como: o individualismo, a igualdade formal (igualdade perante a lei), luta pela liberdade de comerciar por parte da burguesia e a não intervenção do Estado.

Neste cenário, considerava-se como direitos inerentes ao ser humano, sobretudo, o direito à liberdade, à vida e à propriedade, conforme consta na sempre citada Declaração de Independência Americana, de 1776 e a ovacionada Declaração Francesa, de 1789.

Conservadoramente, a identificação dos direitos humanos está ligada com essas circunstâncias histórica, com os direitos individuais do século XVIII e com a subsequente consolidação positivista. Foi nessa dinâmica nas quais eles se firmaram e ficaram intimamente ligados. Contudo, entende-se que decorridos mais de dois séculos da normatização, a estruturação dos direitos humanos abrangem muito mais e surgiram muito antes desse contexto histórico. 
Em que pese à concepção de que o marco histórico da consolidação dos direitos humanos remeterem a Revolução Francesa, esta por sua vez buscou seus fundamentos na teoria jusnaturalista, reconhecidamente anteriores a Idade Moderna e a própria concepção do Estado.

Não há como afastar o contexto histórico da formatação dos direitos humanos. Os primórdios sobre noções de dignidade, as proteções, conquistas, direitos e até restrições se explicam pela história. As necessidades geram as medidas, moldam à sua época. No curso da história tudo se faz e desfaz, se solve e resolve. Toda composição de direitos e deveres da civilização tem a sua necessidade histórica. Desta surgem às providências, as ações, as contradições e toda ciência produzida pelo homem, que no fim se presta a manter sua própria existência.

Na história da civilização humana encontramos a história do Direito. É a partir dessas concepções terminológicas, em que pese à extensão do horizonte histórico, mas amparados na metodologia do historicismo jurídico, que o presente artigo pretende apresentar os precedentes do desenvolvimento dos direitos humanos na civilização ocidental da Idade Antiga até a Idade Média.

\section{A ORIGEM NA IDADE ANTIGA.}

\subsection{Da pré-história ao surgimento da escrita}

Antes do surgimento da escrita pouco se sabe sobre a história da civilização. Foi a descoberta da escrita por volta de mais ou menos 4.000 a 3.500 a.C., no início da Idade Antiga que permitiu que a história começasse a ser revelada. A Idade Antiga é o período que se estende desde a invenção da escrita (de 4000 a.C. a 3500 a.C.) até a queda do Império Romano do Ocidente (476 d.C.).

A evolução dos hominídeos (gênero de grandes primatas) e o surgimento de espécies com aparência mais humana, como o homo erectus e depois o homo sapiens, implicou na primeira evolução organizacional coletiva, com as comunidades tribais (BURNS, 2000). O líder da comunidade sempre era o mais velho, aquele com mais experiência sobre o modo de sobrevivência da tribo. Essas comunidades tribais eram essencialmente nômades, com modo de subsistência predatório e de uso, sem qualquer tipo de cultivo. A passagem para o sistema 
pater famílias (autoridade familiar, econômica e social) surgiu com a prática extrativista do cultivo da terra e domesticação de animais. Elas permitiram que as tribos se estabelecessem, pois com os excedentes e reservas elas não necessitavam buscar fontes de alimentação. Passou-se a adotar a tutela individual da terra, a posse de seus frutos e das pessoas estranhas à sua família, surgindo o escravismo.

Estabelecidas as estruturas familiares, aproximadamente em 1700 a.C., após o surgimento da escrita, em uma época em que os costumes eram transmitidos pela tradição familiar, o Código de Hamurabi representa a primeira codificação das leis. (MORAES, 2009) Elaborado por Hamurabi, o sexto rei da Babilônia, ele foi esculpido em rocha com 282 artigos, disposto em 3.600 linhas de texto e representou uma simbiose entre o que chamaríamos hoje de direito civil e penal, retratando a regulamentando uma série de direitos voltados essencialmente para danos e roubos a propriedade, inclusive sobre os escravos, sem qualquer destaque para questões comuns de dignidade humana.

Retratando a centralização do poder do soberano sobre as entidades familiares, apesar das penas de mutilação e castigos físicos, o único sinal de humanização que o Código de Hamurabi apresentou foi a gênese da lei do talião, da máxima "olho por olho, dente por dente", ao frear a vingança ilimitada do ofendido para impor um controle de pena proporcional ao delito cometido (BITENCOURT, 2007), evidenciando uma nova forma de tratamento jurídico replicada por toda a civilização ocidental.

Contudo, é o Cilindro de Ciro, escrito em 539 a.C. pelo rei da Pérsia (antigo Irã), gravado em um cilindro de barro de 2,25m de altura sobre base de 1,90m com 46 colunas e um texto de 3.600 linhas, que é considerado por grande parte dos historiadores o primeiro tratado do Direito do Homem (ALTAVILA, 1989). E isto porque ele apresentava características inovadoras como a liberdade religiosa e abolição da escravatura, além de um caráter humanitário com o decreto que o rei Ciro autoriza os judeus exilados por setenta anos, a voltarem às suas terras de origem. Trata-se do célebre deslocamento dos judeus exilados atravessando o deserto desde a Pérsia e Babilônia até à terra de Israel e Jerusalém.

Somente no oitavo a sexto século a.C., que a civilização ocidental com os gregos deslocam o centro da vida da família para a cidade, do mundo divino para o mundo das coisas humanas, exigindo regras universais e não só a dos mais velhos, abolindo a justiça familiar. (LOPES, 2000)

Em que pese os posicionamentos sobre a origem dos direitos humanos como fruto da modernidade ou com o cristianismo como pensamento filosófico, para muitos os antecedentes 
históricos da origem dos direitos humanos ocorrem na Idade Antiga, com o direito natural distinguindo o que é justo ou injusto universalmente a partir da condição da natureza humana e não da lei. (LOPES, 2000)

\subsection{Os gregos: os grandes pensadores jusfilosóficos e as reflexões jurídicas}

É na Grécia, nos séculos V e IV a. C. que se referenciam as origens do pensamento jurídico sobre os primórdios a dignidade humana na antiguidade clássica. São os gregos que se afastam da mitologia como centro das questões filosóficas e inauguram o antropocentrismo, rompendo com a tradição mitológica e divina para explicarem a origem da vida através da consciência humana e do pensamento racional. (WOLKMER, 2006)

Para os gregos o indivíduo se realizava dentro e em razão da sua pólis (cidadeEstado). A participação ativa do indivíduo nas funções de governo e a primazia da lei geraram as primeiras instituições democráticas que se tem conhecimento na história. Voltados para o ensino da retórica, dialética e da filosofia, os gregos ensinavam as leis na forma de poema.

Das quatro fronteiras básicas que um território pode ter, a Grécia Antiga possuía três delas voltadas para o mar, ao sul com o Mediterrâneo, ao oeste com o Mar Jônico e ao leste com o Mar Egeu. Essa peculiar localização geográfica lhe proporcionava um intenso comércio e contatos pacíficos com outros povos do Mediterrâneo, para onde se remete os primeiros casos de contratos consensuais.

Nessa dinâmica, a civilização grega inicia o debate sobre a existência de um direito pertencente ao gênero humano, um direito comum ao seu próprio povo e aos estrangeiros (LOPES, 2000). O pensamento grego questiona a ordem natural (physis) e a ordem humana (nomo), e se transforma com a inserção dos problemas sociais, políticos e morais relacionados à condição humana. Símbolo da evolução desses questionamentos foi traduzida pela liderança do legislador e estadista Sólon (640 - 598 a.C.), que depois de trinta anos do primeiro código de leis draconiano ${ }^{3}$, suprime a servidão por dívidas, um inegável avanço no tratamento jurídico.

Os gregos possuíam uma concepção positiva do Direito, de não restrição e o jusnaturalismo perfectibilizou essa visão ao afirmar que os direitos nascem com os seres humanos. Eles pregavam uma vida comedida, de equilíbrio entre tudo, em que a virtude está

\footnotetext{
${ }^{3}$ Drácon (620 a.C.) legislador que ficou conhecido por sua severidade e crueldade, como a punição do roubo com morte. Responsável pela introdução dos diversos tipos de homicídio. Origem da expressão "draconiana".
} 
no meio, e foi através da arte, com as conhecidas tragédias gregas e suas temáticas sobre os extremismos da paixão humana que eles encontraram uma forma de esgotar e explorar suas indagações e emoções para depois apresentarem suas ideias e visão do mundo.

A tragédia grega mais exemplificativa sobre a concepção das virtudes, da lei justa e de direitos inerentes à condição humana é apresentada por Sófocles em sua famosa tragédia Antígona. Ela deu os primeiros passos em direção à doutrina clássica do Direito Natural e ao que viria a se tornar uma das primeiras referências ao direito à dignidade humana.

$\mathrm{Na}$ história, Polícine é assassinado após tentar tomar o poder do rei Creonte. Rompendo com a tradição da época, Creonte proibiu o seu sepultamento e estendeu a pena para aquele que o fizesse. Antígona, irmã de Polícine, desrespeita a ordem recebida e sepulta o irmão, alegando que, acima da ordem positiva do rei, deveria cumprir certas leis não escritas muito mais antigas do que a lei fruto de um capricho ocasional de homem, uma lei que se perde na origem dos tempos. (SOFOCLES, 2005)

Os argumentos de Antígona de resistir à determinação normativa do Estado é o fundo jurídico da defesa de um Direito Natural superior e anterior às leis humanas positivadas. Através do desfecho da tragédia com a punição de Antígona pelo emparedamento e o suicídio de seu noivo Hêmon, filho do rei Creonte e depois de sua própria esposa Eurídice, Sófocles ensina que a lei humana não pode ir contra a boa razão e com o justo porque atinge a todos os moradores da polis.(GONZALEZ, 2005)

As reflexões jusfilosóficas das tragédias gregas e consolidação desses pensamentos inicialmente com os sofistas na figura de destaque de Protágoras (480 - 411 a. C.), depois com Sócrates (470 - 399 a. C.), seu discípulo Platão (427 - 347 a. C.) e na sequência Aristóteles (384 - 322 a. C.) para depois Epicuro (341 - 270 a. C.) geram um direito desmitificado, em que as normas são frutos da convenção humana, mas sempre refletindo sobre os princípios e os fundamentos do justo e da justiça.

Esses grandes pensadores, sempre refletindo o pressuposto de que somente é direito o que é justo, representaram as bases das correntes jurídicas adotadas pela civilização ocidental, respectivamente: (i) relativismo: para os sofistas o Direito é relativo, contingente(ii) o positivismo: para Sócrates o Direito era o estrito cumprimento da lei, e diante do caráter justo da lei, a sua irrestrita obediência era a forma da justiça; (iii) idealismo: para Platão a justiça é o cumprimento, por cada um, do papel que a sociedade impõe aos seus membros, e caberia ao culto legislar sobre a lei ideal e a comunidade se ajustar a ela. A lei possui um caráter educativo e a justiça é a função ética de um Estado; (iv) realismo: para 
Aristóteles a finalidade do direito é a justiça e o bem-comum, é atribuir a cada um o que é seu; (v) contratualismo: para Epicuro justo é o que a sociedade convenciona como utilidade comum.

Após a morte de Aristóteles, outras correntes de pensamento surgiram ${ }^{4}$, mas foram os estóicos, na escola fundada por Zenão de Cício (334 - 262a. C.) ao defenderem que os direitos inerentes ao homem é fruto da mais elevada manifestação de uma razão divina, de uma lei natural universal e suprema, que rege o mundo alicerçado na convivência humana norteados por princípios morais e éticos, que influenciaram o direito romano e chegaram até a filosofia e a teologia moral cristã, pois em 150 a.C. a Grécia submete-se à Roma. (GONZALEZ, 2005)

\subsection{O legado romano}

Se os gregos representaram historicamente a origem do pensamento filosófico, aos romanos a historia reservou o papel de criadores da ciência jurídica (FASO, 1982). As conquistas territoriais proporcionaram aos romanos o contato com vários elementos culturais de outros povos. Esse modo de vida pluralista, a necessidade de agregar o império formado, somado a natureza essencialmente prática e imediatista dos romanos serviram de alicerce para a criação de "um eficiente sistema normativo, funcionando com apurado rigor técnico e permanente segurança.” (WOLKMER, 2006, p. 30)

Na sociedade romana, ao contrário da grega, a família era a unidade produtiva, para depois a cidade. $\mathrm{Na}$ Grécia, a autoridade do pai cessava quando o filho atingia a maioridade, em Roma não, o sujeito de direito por excelência era o pai de família, e dessa relação de autoridade surge a palavra "patrão", de pater (pai) que se reflete principalmente na base economia romana, a agricultura. Era a aristocracia rural que exercia autocraticamente o governo de Roma, através do modo de produção escravo e alcançado com a esmagadora expansão militar de dominação territorial e transformação da população ocupada em escravos.

Não podemos nos afastar da perspectiva história de que a civilização romana perdurou por aproximadamente doze séculos, iniciando por volta do ano de 750 a.C. com a fundação de Roma até a queda do Império Romano em aproximadamente 400 d.C.. Diante deste extenso decurso de tempo, impossível não se retratar mudanças de todas as ordens.

\footnotetext{
${ }^{4}$ Para maiores aprofundamento sobre outras correntes, como os cínicos fundamentados nos pensamentos de Diógenes ver NAVIA, Luiz. E. Diogenes, o Cínico. São Paulo: Odysseus, 2010.
} 
Neste cenário, e voltados somente para as conquistas dos direitos humanos sobressai no campo das leis, a Lei das XII Tábuas, e do pensamento filosófico Cícero.

A Lei das XII Tábuas é considerada a fonte de todo o direito público e privado romano, mas consolida a influência grega, porque teve sua base nas leis de Sólon. Com as transformações do período da realeza, foi criada no período republicano e representou uma das primeiras conquistas contra o arbítrio do Estado e segurança jurídica. E isto porque a magistratura era essencialmente exercida pelos patrícios (classe mais privilegiada que gozava de direitos civis e políticos) “(...) que julgavam segundo tradições que apenas eles conheciam e aplicavam. A incerteza na aplicação do direito, por parte dos magistrados patrícios, levou a plebe a pleitear a elaboração de leis escritas.” (VERAS NETO, 2001, p. 127).

No campo jusfilosófico Cícero (106 - 43 a. C.) foi o pensador de maior expressão da cultura romana, foi também o maior intérprete e divulgador da doutrina estóica, ao valer-se de todos os ensinamentos do estoicismo grego e sustentar que todas as condutas devem seguir uma "reta razão", porque a razão é o que distingue o homem e o liga a Deus, pois “(...) a república pressupõe Direito, e o Direito pressupõe leis, e as leis pressupõem leis naturais, e as leis naturais pressupõem Deus. Assim, a investigação ciceroniana em torno do problema da justiça, da virtude e do Direito se entrelaça com razões cósmicas, com razões naturais." (BITTAR, 2001, p. 146)

No período imperial e pós-clássico ocorre à cristianização do Império Romano. Mesmo com a limitação do poder político fato considerado para muitos o mais significativo para a evolução das ideias no campo dos direitos humanos.

O cristianismo foi um marco histórico que, por um lado, constitui-se nem dos fatores do declínio da filosofia Antiga e por outro, uma das causas do surgimento da Idade Média. Sob o aspecto jurídico, pode-se dizer que o cristianismo trouxe valores novos e contribuiu para o surgimento de uma teoria jurídica que, séculos depois, ainda se encontra presenta na cultura Ocidental. Além disso, é inegável a contribuição do cristianismo para a construção da concepção de direitos interligados a humanidade, na medida em que, com o surgimento do cristianismo, todos os homens passar a ser considerados irmãos e iguais perante o Pai, irmãos e iguais em direitos e deveres, independentemente da etnia, cor ou pátria. (GONZALEZ, 2005, p. 131) 


\section{IDADE MÉDIA: DIREITOS PARA TODOS OS HUMANOS?}

A expressão habitual utilizada pelos historiadores que marca o início da Idade Média e o final da Idade Antiga é a chamada "queda de Roma", no entanto seria mais apropriada fragmentação de Roma, que se iniciou por volta do ano 400 d.C. Muitos atribuem a "queda de Roma" a invasão dos bárbaros ${ }^{5}$.

Várias são as causas para explicar a dissolução do império romano, porém nem todas são verdadeiras, assim como não aconteceu de um dia para outro. Internamente, as causas mais coincidentes trazidas pelos historiadores foram: a falta de clareza da sucessão dos imperadores que trazia instabilidade política, o sistema de mão de obra escravista (quanto mais crescia, mais Roma precisava dos escravos, porém dependia destes para crescer), as frequentes batalhas que despendiam muitos recursos materiais e humanos, baixa tecnologia agrícola, perda do ideal cívico pela causa romana etc. (BURNS, 2000)

Pierre Grimal (2010) aponta outras causas concomitantemente influentes como: as extensas fronteiras difíceis de serem mantidas e vigiadas, as ditaduras militares impostas com o argumento de conterem o perigo das invasões dos bárbaros - sob lei marcial era eleito um ditador, que deveria fazer o que fosse necessário para reestabelecer a ordem - , as rebeliões de escravos e militares, assim como o aumento do contingente da administração pública, que constituía um gasto sem retorno ao império, e principalmente a indisposição dos ditadores com a velha aristocracia romana.

Sobretudo, pode-se afirmar que a causa historicamente mais importante da dissolução de Roma foi a separação do império em Ocidental e Oriental. "Constantino, que tomará o poder após as guerras civis que marcaram o fim da 'tetrarquia' ${ }^{6}$, vai lhe dar o golpe fatal, criando uma segunda capital às margens do Bósforo, a Cidade de Constantinopla"7 . Constantino teve várias razões para tal façanha, dentre elas por vislumbrar uma nova Roma, com grande potencial econômico, estabilidade política e religiosa (GRIMAL, 2010)

\footnotetext{
${ }^{5}$ Para o povo grego bárbaros eram todos aqueles estranhos ao seu povo, a palavra também foi utilizada pelos romanos para denominar os povos estranhos não civilizados, anglos, germanos, godos, saxões, vândalos, francos etc. Para os gregos os romanos também eram bárbaros. (BURNS, 2000, p. 148) No final do século I a.C. O Império Romano tomou conta de quase todo continente europeu e continuava se estender ao norte do continente africano e ao Oriente, de tal forma que o mar mediterrâneo passou a ser um "lago romano". Em que pese não existir exatidão no marco da dissolução do império romano, as invasões bárbaras começaram em meados de 300 d.C., marcada pela mais invasiva delas em 410 d.C., com o saque de Roma pelos visigodos. (BURNS, 2000).

${ }^{6}$ A tetrarquia foi uma forma de controle político de Roma, sobretudo para enfrentar a invasão de impérios inimigos e dos bárbaros, dirigida por quatro césares (Diocleciano, Constantino Cloro, Galério e Maximiano), um em cada região periférica do império.

${ }^{7}$ Constantinopla foi a antiga Bizâncio, Império Bizantino, batizada de Constantinopla após a morte de Constantino, atual Istambul na Turquia.
} 
A expressão "Idade Média"8 foi criada pelos europeus no século XVIII, a fim de explicarem seu entendimento do período das "gloriosas realizações da Grécia e Roma clássicas" e o estado que se encontravam, a Idade Moderna (BARROS, 2003). Essa fase da história está mais ou menos entre os anos 600 a 1500 d.C. Os historiadores europeus também convencionaram dividir a Idade Média em três partes: a Idade Média Inicial (grande atraso econômico e social da civilização cristã ocidental em relação aos impérios bizantino e islâmico), a alta Idade Média (grande avanço econômico, sobretudo pelo progresso na agricultura) e a Idade Média tardia (declínio econômico pela exaustão do solo, peste negra, guerras) (BURNS, 2000).

\subsection{De escravo a servo: o feudalismo e a fidelidade em busca de proteção}

Não há uma só razão que fundamente a formação dos feudos na Idade Média, no entanto é possível afirmar que o modo de produção feudal era semelhante por toda a Europa. Sumariamente, a formação dos feudos começa após a fragmentação de Roma. Os grandes proprietários de terras, aristocratas, grandes generais, mosteiros etc., das diversas regiões da Europa, dentro dos territórios dos novos impérios que se formavam, cercaram vigorosamente suas propriedades e mantiveram soldados para protegerem as fronteiras dos impérios e suas terras da invasão dos bárbaros, que haviam atacado os antigos domínios romanos e se fixaram por toda parte. Ao mesmo tempo em que protegiam suas propriedades, protegiam também o império que não detinha recursos suficientes para defender seu território e manter sua soberania. (PINKS, 1986)

Os feudos eram organizações sociais unitárias na qual surgiu um novo modo de produção econômica, o modo de produção feudal ou feudalismo, basicamente agrícola (realizada por "colonos", em uma relação servil e de vassalagem); formado pela propriedade da terra de um Senhor, que detinha o poder político, econômico, judicial, social e territorial (inclusive sobre as pessoas que estavam nele), foi a retomada da unidade de poder, advinda dos pater familias tribais (BARROS, 2003). Em sua maioria, eram constituídos por uma, ou mais edificações centrais, na forma de castelos, bem protegidas, com muralhas e soldados próprios, num contornado de terras na qual extraiam a subsistência.

\footnotetext{
${ }^{8}$ No processo histórico de fragmentação do Império romano surgiram no ano 700 d.C. três civilizações sucessoras, que viriam a marcar o fim da unidade romana: a civilização Bizantina (parte baixa do continente, mar mediterrâneo, península itálica, Grécia etc., linhagem direta da Roma), a civilização cristã Ocidental (maior parte da Europa central, Império Germânico, Espanha, França, Inglaterra) e a civilização Islâmica, sendo nas duas primeiras o modo de produção feudal, ou feudalismo, estudado com mais profundidade pelos historiadores ocidentais na chamada Idade Média. (BURNS, 2000, p. 199).
} 
A força produtiva advinha essencialmente dos servos da gleba, formada por agricultores das colônias romanas, antigos escravos e até camponeses livres, que em busca de proteção se submetiam ao Juramento Feudal ou de Lealdade ${ }^{9}$ e obtinham oportunidade para cultivar e viver da terra ${ }^{10}$. O juramento feudal era o ato solene pelo qual o servo da gleba jurava fidelidade a um senhor feudal ${ }^{11}$, tendo o direito de viver e cultivar a terra, mediante pagamento de parte extravagante de sua produção. Da mesma forma um nobre fazia o juramento ao Rei, para que em seus domínios mantivesse seu feudo - com a função precípua de defender e manter o território -, em troca de pagamento com parte de sua produção agrícola, além de pagar impostos e taxas das mais diversas naturezas, como, por exemplo, a de exoneração para lutar em caso de guerra, dependendo do reino. (PINKS, 1986)

É inegável a evolução da condição humana da classe social produtora com a mudança do escravismo para o feudalismo. O escravo de coisa passa a ser pessoa, "servo da terra", deixando de ser "servo do homem", e ainda que numa relação de subserviência com pouquíssimos direitos e exacerbados deveres, começa a ser, ainda que timidamente sujeito de "direitos", com relativa liberdade. Entretanto, haviam exceções, na Itália por exemplo restava ainda muita agricultura baseada na escravidão, e na Alemanha central e oriental eram muitas as pequenas fazendas trabalhadas por camponeses livres. (PINKS, 1986)

Progressivamente nasce uma composição de direitos e deveres na Idade Média, entre a relação do senhor feudal com o servo da gleba, assim como na relação dos reis para com os senhores feudais (vassalagem ou suserania) - ambas constituíam relação desproporcionais, pior ainda a dos servos da gleba, que pouco podiam reivindicar, contudo não deixam de ser uma relação de direitos e deveres.

De forma genérica o direito feudal era essencialmente costumeiro, dependendo de império para império e de região para região feudal, sem sofrer intervenção direta de

\footnotetext{
9 “Conquanto sem ter ainda a conotação individualista, que sobreveio, forte, ao Humanismo renascentista, mesmo assim foi ao longo da Idade Média que se formou a noção de que na relação de governo hom tem direitos, com os quais suas obrigações sociais se correlacionam. No desenvolvimento dessa noção, ocupou lugar especial o juramento de lealdade ou de fidelidade, que deu base à vindicação de cumprimento de deveres por um lado, bem como à satisfação a direitos do outro lado, no feudo, entre o vassalus e o sênior (na alta Idade Média dito também suseranus) e, na comuna, entre os burgueses, reciprocamente." (BARROS, 2003. p. 174 e 175.)

${ }^{10}$ Inicialmente o vassalo tinha somente a posse da terra, mas não tinha a propriedade, deveria dar a maior parte da sua produção ao dominus da terra, o senhor feudal, porém com o tempo passou a ter o direito poder de comprar e herdar a terra. (PINSKY, 1986, p. 75)

11 “Aquele que jura fidelidade ao seu senhor deve ter sempre em mente estes seis princípios: proteção, segurança, honra, interesse, liberdade, faculdade. Proteção, quer dizer que nada deve ser feito em prejuízo da residência onde ele habita ou de suas fortalezas nas quais ele possa se achar. Honra, quer dizer que nada em detrimento de sua justiça ou de que possa sua honra depender. Interesse, quer dizer nada que possa prejudicar suas possessões. Liberdade e faculdade, quer dizer que o bem que o senhor possa fazer não lhe deve ser tornado difícil e o que ele esteja fazendo tornado impossível." Carta do Bispo Fulberto ao Glorioso duque de Aquitânia, Guilherme (1.020 d.C.). Fulbert de Chartres, Epistolae, LVIII, ann. 1020; H. F., X, p. 463, (PINSKY, 1986, p. 65 e 66.)
} 
legislação específica, havendo inexistência de uma fonte formal do direito, contrariamente do que ocorria em Roma.

A mão de obra não deixa de ser escrava a toa, tornou-se muito custoso manter o escravismo. Em verdade houve uma crise geral no sistema escravista, além do que o servo poderia lutar em caso de guerra ou invasão, mediante pagamento ou convocação, o que era mais difícil com o escravo que sempre tentaria a liberdade, não obstante haviam grandes de insurgências aliada a baixa motivação para a produção. (PINKS, 1986)

\subsection{Os privilegiados e o direito}

Na Idade Média havia basicamente três classes sociais bem definidas: a nobreza, composta pela figura principal de um Rei e demais nobres como os súditos diretos destes, conselheiros, oficiais de governos, generais etc., e os possuidores de terras cedidas ou incorporadas pelo império, como os barões, marqueses, duques, cavalheiros etc.; o clero, formada por sacerdotes que receberam o sacramento, como o Papa (figura política central), cardeal, bispo, arcebispo, monges etc., divididas em alto clero e baixo clero; e os servos da gleba, a classe produtora explorada pelas duas anteriores, inicialmente sem nenhuma perspectiva de sair dessa condição, com exceção da possibilidade de virem a compor o baixo clero.(BURNS, 2000)

A Igreja Católica continuou com grande poder na Idade Média inicial, desde sua afirmação por Constantino no Império Romano (por volta do ano de 312 d.C.) ${ }^{12}$, de tal sorte que os Papas é que ungiam e coroavam os reis; sem o coroamento pelo Papa o sucessor do trono não se tornava rei, se assim não fosse os súditos não lhes deviam obediência. O poder do rei era fundamentado na "teoria do direito divino", sobrenatural poder conferido pela graça de Deus. Com o passar do tempo os monarcas passam a ter mais poder, prescindindo da chancela da Igreja, pela força passam a serem realmente absolutos no sentido mais moderno desse termo. Esse absolutismo da monarquia somente será superado com o ideário liberal do legalismo, que lutará para submeter o rei às leis, nascendo a concepção de Estado de Direito.(BARROS, 2003)

\footnotetext{
12“A adoção do cristianismo pelo Império Romano foi iniciada por Constantino e completada por Teodósio. Constantino não chegou a tornar o cristianismo religião oficial do império, mas favoreceu-o claramente. É provável que o tenha feito porque associou sua própria conversão à fé (por volta de 312) com a ascensão de sua estrela política e por esperar que o cristianismo trouxesse unidade espiritual a um império que passava por uma grave crise de desmoralização e de uma divisão religiosa”(BURNS, 2000, p. 179.
} 
Apesar da intitulação de alguns historiadores como "período negro da história" ou "idade das trevas", sobretudo pelo sobrestamento da filosofia greco-romana, a Idade Média foi uma época realmente importante do ponto de vista social, com vários contributos culturais, artísticos e filosóficos. Na realidade a filosofia greco-romana, especialmente grega, serviu de base à construção de uma "fillosofia cristã", que teve papel importante aos direitos humanos. (GONZALEZ, 2005)

Basicamente toda produção intelectual e científica estava nas mãos da Igreja, a massa trabalhadora não tinha nenhum tipo de educação formal, e ainda, mesmo nos mosteiros, e até mesmo entre os nobres, a leitura e escrita era um privilégio de poucos, a infraestrutura do clero era analfabeta, com exceção de escribas monásticos incumbidos de reproduzir obras importantes da literatura antiga, isso pelo menos até a alta Idade Média. (BURNS, 2000)

Entretanto, essa filosofia cristã não se difundiu na prática, principalmente fora dos mosteiros e escolas eclesiásticas, pois a população continuava a sofrer abusos e perseguições da Nobreza, dos Senhores e, no final da Idade Média, principalmente do Clero com a instituição da Inquisição. A campanha das cruzadas para retomar a Terra Santa (antiga palestina, hoje dividida entre o Estado de Israel, Faixa de Gaza e Cisjordânia), assim como a grande campanha da Igreja em manter uma monarquia papal, encabeçada por Gregório VII, seu maior expoente, fez com que a Igreja focasse "no fortalecimento de sua administração jurídica e financeira", para tanto "alguns leigos começaram a imaginar a Igreja, antes tão inspiradora", estaria perdendo seus objetivos idealistas, o que fez crescer grandes movimentos de "heresia popular", nos quais surgiram outras religiões pagãs, incialmente na segunda metade do século XII. A reação da Igreja, sob o comando de Inocêncio III, foi imediata e vigorosa no combate as heresias em uma estratégia dupla, de um lado resolveu aniquilar toda desobediência contra a autoridade do Papa, de outro apoiar todos os grupos religiosos dispostos a apoiar sua autoridade (como a ordem dos dominicanos, franciscanosetc) (BURNS, 2000). Foi o nascimento da Inquisição ou Santo Ofício, com ainstituição dos tribunais eclesiásticos para julgar os hereges, criados pelo Concílio de Latrão de 1215, que determinava um procedimento ex oficio sem necessidade de acusação formal. (SILVA, 2007)

“O papado aprovou o emprego da tortura em julgamentos inquisitoriais, e a queima na fogueira tornou-se a punição mais comum para a desobediência religiosa" ${ }^{13}$, manchando

\footnotetext{
${ }^{13}$ Os réus eram julgados por uma crise de fé e as penas serviam tanto para purificação como para a intimidação popular (penitências, confiscos, morte, fogueira, mutilações etc.). $\mathrm{O}$ frenesi do combate aos hereges foi tamanho que inspirou até algumas produções intelectuais sórdidas, com o "manual do inquisidor", directorium inquisitorum (obra sobre técnicas primitivas de persuasão psíquica e física, com
} 
para sempre a reputação da Igreja Católica e criando o grande paradoxo de seus ideias humanísticos e igualitários. A justificativa desse sistema era principalmente o combate à heresia e a manutenção do monopólio religioso.

No processo histórico de formação dos direitos do homem, nenhum outro ramo acadêmico é mais rico de informações, para avaliar o nível de respeito a esses, como o direito penal. Aliás, na Idade Média a utilização da expressão “direito penal” não seria a mais adequada, pois esta supõe uma série de garantias que nessa fase da história não existiam, ao menos difusamente, para tanto a mais apropriada seria repressão penal.

Conforme mencionado o direito feudal era marcado pela descentralização e regionalidade, não sendo diferente a repressão penal. Ressalvados os crimes de lesa majestade ou lesa pátria, que afrontavam diretamente a soberania real, dependiam da região feudal onde o "crime" ocorrera, sem prejuízo da avocação real ou eclesiástica, esta última focada na repressão contra os hereges (não há indícios de respeito ao princípio do non bis in idem). Todavia, pode-se afirmar era marcado pela crueldade das penas, desigualdade e confusão (sobre crime, vício, pecado, moral e costumes), dependia da região, da condição social, econômica e política do infrator e do responsável pela aplicação da pena. As penas tinham como características a crueldade, intimidação, execrações públicas, constrangimentos vexatórios, torturas, etc. ${ }^{14}$

\subsection{Primórdios dos direitos declarados - law of the land}

Nesse contexto histórico, a partir da segunda metade da Idade Média, outra contradição se agrava sem conduto virar uma revolução. As perseguições e explorações reais começam a se tornar insuportáveis para os barões, sobretudo em relação aos impostos, confiscos e tributos de guerra, que unidos começam a exigir limites por meio de documentos. "Em toda Europa encontram-se exemplos, não de registro de direitos do Homem, mas de direitos de comunidades locais, ou de corporações, por meio de forais ou cartas de franquia", que continham direitos "próprios e peculiares aos membros do grupo", a fim de serem conhecidos e respeitados continuamente. (FERREIRA FILHO, 2010).

métodos especiais de tortura) e um "manual de caça as bruxas", malleus maleficarum (a tradução real é martelo do mal, maléfico, ímpio). Interessante que a caça às bruxas foi mais intensa no final da Idade Média e perdurou até após a revolução protestante, qual foi mais intensa, matou milhares de pessoas acusadas de bruxaria em sua maioria mulheres. (PINSKY, 1986, p. 95)

14 As penas mais comuns eram a pena de morte natural (enforcamento simples, com direito de ser enterrado), morte para sempre (enforcamento até a esqueletização), fogueiras com o réu vivo, soterramentos, açoites, marcas corporais, mutilações, roupas marcadas, adereços, boina de chifre etc.( NORONHA, 2011. p. 31). 
Os barões ingleses passam a exigir a aplicação da law of the land, a lei da terra, a lei dos antigos donos da terra, dos antigos pater familias, na tentativa de resgate das tradições e antigos costumes tribais, a lei de sua terra. Com o tempo essas leis passam a ser exigidas uniformemente, compondo um "sistema" costumeiro de direitos, a common law, a "lei comum". O que pretendiam os barões ingleses era a afirmação do rule of law, sujeição de todos, em especial do rei, ao "império do direito". Rule of de Law "é a expressão da common law", base do direito inglês, que a partir do século XII começou a se desenvolver na medida que as cortes reais foram consolidando a law of the land, "que até antão variava de região para região. (FERREIRA FILHO, 2010). Tal seleção se cristalizou em razão do stare decisis, pelo qual os juízes inferiores têm de se conformar com o entendimento dos tribunais superiores"15. Tudo isso passou a compor o direito inglês e posteriormente seria herdado pelo direito norte americano. Essa evolução do direito contribuiu muito para a afirmação da doutrina dos direitos humanos fundamentais.

Como exemplo a Magna Carta de 1215 merece especial destaque, principalmente por trazer um rol de direitos e garantias que futuramente constituirá a base do direito inglês, apesar dos vários outros pactos não menos importantes. Além de afirmar a imemorial law of the land, trazia várias prerrogativas aos súditos do rei, versando especialmente sobre limitação de poder, como judicialidade (crivo de um Juiz em caso de qualquer prisão, julgamento de seus pares segundo a law of the land), jus ambulandi, direito a propriedade privada, graduação da pena conforme o delito, no taxation without representation etc. (FERREIRA FILHO, 2010)

\subsection{Os "pés poeirentos"16: a nova classe social e dinâmica de direitos}

Concomitantemente a esse contexto de composição de direitos e deveres feudais, é com o surgimento de uma nova classe social, a burguesia, que os rumos da civilização ocidental, bem como de todo direito ocidental iria mudar radicalmente, marcando a mudança do modo de produção feudal para o mercantilismo e deste ao capitalismo.

\footnotetext{
${ }^{15}$ É o stare decisis uma condição jurisprudencial natural ao common law. Nasceu com ele espontaneamente. Estendeu-se até onde ele se impôs. Assim chegou aos Estados Unidos. Originário de um tempo em que o latim ainda era a língua em que se comunicavam as ciências, inclusive o Direito, sua expressão completa é stare decisis et non quieta movere. Tradução literal: estar com as coisas decididas e não mover as coisas quietas. Vale dizer: juízes e tribunais inferiores devem estar com as decisões da Corte superior e não mover as decisões pacificadas. Ou seja: a jurisprudência pacífica tem um efeito vinculante." (BARROS).

${ }^{16}$ Pedes pulverosi ou piepowdrous, os pés poeirentos eram mercantes ambulantes que foram se multiplicando e se estabelecendo nos burgos. “Assim, pitorescamente, os textos ingleses do século XII definiam os mercadores que vagavam livremente pelo reino.”( BARROS, 2003. p. 254)
} 
Os burgueses iniciaram como mercantes ambulantes, o que hoje chamaríamos de "caixeiros viajantes", transitavam pelos reinos comercializando "produtos" de uma região a outra, produtos estes que não estavam à disposição da nobreza nas regiões da Europa (especiarias como tafetá, alimentos, sedas, temperos, etc.), vinham geralmente do oriente, por meio de outros comerciantes navegantes pelo mar mediterrâneo e eram levados Europa acima, ou produtos e frutos que existiam em uma região da Europa, mas eram inexistentes em outras. A nobreza era o principal cliente desses comerciantes, nessa época na Europa os utensílios eram muito rudimentares e os tecidos das roupas "grosseiros". É a "revivescência do comércio" na Europa ocidental constituído uma verdadeira "revolução urbana". (BARROS, 2003).

Com o estabelecimento desses comerciantes nos "burgos"17 (baixo latim burgus, de origem germânica, que quer dizer arrabalde de cidade ou vila, aldeia, civil etc.), principalmente nas margens dos castelos e em cruzamentos de estradas de um feudo a outro, começam a se formar as comunas, cidades que vão se emancipando, se tornado autossuficientes, centradas em razão dos mercados, nos quais ocorriam o comércio burguês. É o início do mercantilismo, marcado pela formação de uma nova sociedade, a sociedade burguesa (futuramente sociedade civil, a sociedade dos cidadãos) (BARROS, 2008).

Surgem os primeiros maquinários (pela força da água, dos animais, do vento e do homem) e as fábricas. Os burgueses começam a produzir suas próprias mercadorias ao invés de importá-las, surgem as corporações profissionais ou guildas de ofícios ${ }^{18}$ (associações profissionais primitivas) para proteger e promover o comércio, isso contribui sobremaneira para o acúmulo de capital, que desemboca futuramente no capitalismo liberal. Muitos servos passam a trabalhar para os burgueses, o que traz uma nova perspectiva de vida e uma chance de ascensão social, era melhor trabalhar de "sol a sol" nas fábricas e mercados do que na gleba aos senhores, onde de geração em geração nasciam e morriam como servos. (BURNS, 2000)

Com o aumento do poder econômico, em apoio recíproco, a burguesia e os barões exigiam direitos baseados no rule of law e liberdade mercantil. A influência política ante a

\footnotetext{
${ }^{17}$ Em alemão bürgerlich, adjetivo, quer dizer civil, cívico, burguês etc. Assim explica Sérgio Resende de Barros: "No léxico jurídico como no comum, bürger e derivados denotam a ideia de burguês, equivalente a civil em português. Exs. Bürgerkrieg (guerra civil), Bürgerliches Gesetzbuch (Código Civil), Bürgerliches Recht (Direito Civil) (...)”. (BARROS, 2008. p.13.)

18 As funções principais das guildas consistiam em manter um monopólio de mercado local para seus membros e preservar um sistema econômico estável. Em geral, seus únicos membros plenos, com direito a voto, eram os chamados artífices-mestres, exímios em seus ofícios e que possuíam suas próprias lojas. As condições de aprendizado eram cuidadosamente regulamentadas: se um aprendiz desejasse tornar-se mestre tinha muitas vezes de produzir uma 'obra prima', a ser julgada pelos mestres da guilda.” (BURNS, 2000, p. 248).
} 
nobreza vai aumentando paulatinamente por meio dos conselhos, corporações e patrocínio direto aos nobres, inclusive se inicia uma convivência e tolerância. Ocorre uma ruptura real entre o agenciamento político e econômico.

No processo histórico de reunião dos feudos, pelo capitalismo burguês, há uma padronização das cidades que vão lentamente se transformando em nações sob a chefia de um príncipe ou magistrado. Formam-se três classes bem distintas o Estado, o Clero e o terceiro Estado - burgueses, proprietários de terra, camponeses e pessoas comuns do povo, muito embora a representação política somente fosse exercida pelos dois primeiros.

Na Idade Moderna, essa dicotomia entre sociedade civil liderada pela burguesia e a sociedade política detentora do poder de legislação fez surgir o Estado Nacional, afastando o absolutismo como regime político e alcançar representação e pouco depois consubstanciado na imposição de um pacto de legitimação, o constitucionalismo, fruto das Revoluções Liberais, a Independência dos Estados Unidos em 1776 e a Revolução Francesa em 1789.

\section{CONSIDERAÇÕES FINAIS}

A análise de fenômenos do passado através do método histórico permite a constatação de eventual processo de continuidade e de entrelaçamento entre os fenômenos. Através desse método histórico investigativo dos acontecimentos, da dinâmica e instituições do passado, o objetivo foi apresentar a sua influência na sociedade contemporânea e melhor compreender o papel que atualmente desempenham na sociedade.

Atualmente, ouvir ou falar sobre direitos humanos é assunto cotidiano, com repercussões e dimensões que atingem as mais diversas partes do mundo, de várias concepções, em graus e aplicabilidades diversas. O oprimido reivindica seu direito, as organizações reivindicam efetividade, principalmente aquele a quem se ofende a dignidade humana, usualmente concebida como condição e qualidade moral intrínseca a todos os homens e mulheres.

Nem sempre foi assim. Nem sempre ao oprimido houve um direito humano a socorrêlo. Já houve época em que até mesmo a condição de humanidade foi negada. E um dos objetivos deste artigo foi exatamente esse: contextualizar os primórdios dos direitos humanos entre a Idade Antiga e a Idade Média na histórica da civilização ocidental. 
Para isso, o artigo considerou o percurso histórico-jurídico das dinâmicas que afetaram essas populações neste recorte temporal, revelando o encadeamento de épocas de coerção e de oportunidade.

A história dos direitos humanos é a história da própria civilização. De tal forma que não se pode desconsiderar a interferência da vontade humana no poder, e logo no Direito, que é movido pelo homem, seu ideal, sua compaixão, a solidariedade, mas também a ganância e o menosprezo a outro ser de sua espécie.

De um estágio primitivo comunitário, em que tudo era de todos, o homem passa a se sentir dono da terra e de tudo que há sobre ela, inclusive outros homens. É o início de uma odisseia em que o homem tiraniza o próprio o homem, e direitos são reivindicados à liberdade do homem contra o próprio homem, e consequentemente, contra o Estado.

Conclui-se que é inegável o avanço dos direitos humanos no contexto histórico da civilização ocidental, sobretudo na sua finalidade: buscar a garantia de direitos individuais contra o arbítrio estatal, reconhecidos embrionariamente no período da Idade Antiga a Idade Média na civilização ocidental pelos avanços de liberdade contra os regimes de escravidão e a tirania dos regimes políticos, das autoridades e hierarquias sociais que servirão de fundamento para as liberdades públicas e o constitucionalismo.

\section{REFERÊNCIAS}

ALTAVILA, Jayme. Origem dos direitos dos povos. São Paulo: Ícone, 1989.

BARROS, Sérgio Resende de. Direitos humanos: paradoxo da civilização. Belo Horizonte: Del Rey, 2003.

BARROS, Sérgio Resende de. Contribuição dialética para o constitucionalismo. Campinas: Millennium, 2008.

BARROS, Sérgio Resende de. Simplificação do controle de constitucionalidade. Disponível in http://www.srbarros.com.br/pt/simplificacao-do-controle-de-constitucionalidade.cont. Acesso em 16.10.16.

BARROS, Sérgio Resende de. Noções sobre as Gerações de Direitos. Disponível em<http://www.srbarros.com.br/pt/tres-geracoes-de-direitos.cont>. Acesso em 16.10.16.

BECCARIA, Cesare. Dos delitos e das penas. Trad. Torrieri Guimarães. $1^{a}$ ed. São Paulo: Hemus, 1974.

BETTENCOURT, Estevão. Inquisição.Disponível em<http://www.alfredobraga.pro.br/inquisicao.html>. Acesso em 04.11.11. 
BITTAR, Eduardo e C.B. ALMEIDA, Guilherme Assis de. Curso de Filosofia do Direito. São Paulo, Atlas, 2001.

BURNS, Edward McNall; LERNER, Robert E.; MEACHAM, Standish.História da Civilização Ocidental. vol. 1. 44 ed. Tradução de Donaldson M. Garschagen. São Paulo: Globo, 2000.

CASTARDO, Hamilton Fernando; CANAVEZZI, Gustavo Escher Dias; NIARADI, George Augusto. Lições de Direito Constitucional em Homenagem ao Prof. Dr. Sérgio Resende de Barros. Campinas: Millennium, 2007.

COMPARATO, Fábio Konder. A Afirmação Histórica dos Direitos Humanos. $7^{\mathrm{a}}$ ed. São Paulo: Saraiva, 2010.

DALLARI, Dalmo de Abreu. Elementos de Teoria Geral do Estado. 19a ed. São Paulo: Saraiva, 1995.

FASSO, Guido. Historia de la Filosofia delDerecho: antigüedad y edad media. Madrid: Pirâmide, 1982, v. 1.

FERREIRA FILHO, Manoel Gonçalves. Curso de direito constitucional. 36 ed. São Paulo: Saraiva. 2010.

FERREIRA FILHO, Manoel Gonçalves. Direitos Humanos Fundamentais. 12a ed. São Paulo: Saraiva. 2010.

GARDENAL, Emerson Marinaldo. História do Direito Penal Brasileiro - 1500 a 1940. Piracicaba: Moinho Editorial. 2011.

GRIMAL, Pierre. História de Roma. Tradução de Maria Leonor Loureiro. São Paulo: UNESP, 2010.

GONZALEZ, Everaldo TadeuQuilici; VELAZQUEZ, Victor Hugo Tejerina. Direito e Política. $11^{\mathrm{a}}$ ed. Piracicaba: UNIMEP, 2006.

GONZALEZ, Everaldo T.Q. A Filosofia do Direito na Idade Antiga. Rio Claro: Obra Prima Editora, 2005.

KURY, Adriano da Gama. Dicionário da Língua Portuguesa. $1^{a}$ ed. São Paulo: FTD, 2001.

LAFER, Celso. A Reconstrução dos Direitos Humanos: Um diálogo com o pensamento de Hannah Arendt. São Paulo: Companhia das Letras, 1998.

LOPES, José Reinaldo de Lima. O Direito na História: lições introdutórias. São Paulo: Max Limonad, 2016.

MAQUIAVEL, Nicolò. O Príncipe. Tradução de Lívio Xavier. São Paulo: Edipro, 1994.

MARTINS, Argemiro Cardoso Moreira. O Direito Romano e seu ressurgimento no final da Idade Média, in WOLKMER, Antônio Carlos (org.) Fundamentos de história do direito. 2ed. rev. e ampl. Belo Horizonte: Del Rey, 2002.

MONTAGNER, Airto Ceoli; SILVA, Amós Coêlho da. Dicionário Latino-Português. Petrópolis: Vozes, 2009.

MORAES, Alexandre de. Direitos Humanos fundamentais: teoria geral, comentários aos arts. $1^{\circ}$ a $5^{\circ}$ da Constituição Federativa do Brasil, doutrina e jurisprudência, São Paulo: Atlas, 2015.

NORONHA, E. Magalhães. Direito Penal. São Paulo: Saraiva, 2004. 
PINSKY, Jaime; PARAIN, Luis Vitale; CAHEN, S.I. Kovaliev.Modo de Produção Feudal. $4^{\mathrm{a}}$ ed. Rio de Janeiro: Global, 1986.

SILVA, José Afonso da. Curso de direito constitucional positivo. $39^{a}$ ed. São Paulo: Revista dos Tribunais, 2016.

SILVA, José Geraldo da. Teoria do Crime. $3^{\mathrm{a}}$ ed. Campinas: Millennium, 2007.

SÓFOCLES. Antigone. Tradução J. B. de Mello e Souza. Versão para eBook. Fonte Digital. Digitalização do livro em papel. Clássico Jackson, Vol. XXII, 2005.

VÉRAS NETO, Francisco Quintanilha. O direito romano clássico. In: WOLKMER, Antonio Carlos (org.). Fundamentos de história do direito. 2a ed. Belo Horizonte: Del Rey, 2001.

WOLKMER, Antônio Carlos. Síntese de uma História das Ideias Jurídicas: da antiguidade clássica à modernidade. Florianópolis: Fundação Boiteux, 2006. 